\title{
IMPROVEMENT OF SIMVASTATIN DISSOLUTION RATE USING DERIVATIVE NON-COVALENT APPROACH BY SOLVENT DROP GRINDING METHOD
}

\author{
IYAN SOPYAN ${ }^{1,2}$, INSAN SUNAN KURNIWAN SYAH ${ }^{1}$, DESI NURHAYTI ${ }^{1}$, ARIF BUDIMAN ${ }^{1}$
}

1Departement of Pharmaceutics and Technology of Pharmacy, Faculty of Pharmacy, Universitas Padjadjaran, Bandung, Indonesia, ${ }^{2}$ Pusdi Drug Delivery and Disposition, Faculty of Pharmacy, Universitas Padjadjaran, Bandung, Indonesia

Emai: i.sopyan@unpad.ac.id

Received: 24 Sep 2019, Revised and Accepted: 04 Nov 2019

\section{ABSTRACT}

Objective: This study aimed to enhance the solubility of simvastatin using noncovalent derivatives (NCDs) with oxalic acid (OA), fumaric acid (AF), and nicotinamide (NK) as conformers.

Methods: NCDs were prepared using by a solvent drop grinding (SDG). The NCDs formed were evaluated for saturated solubility test, NCDs with the highest saturation solubility were then characterized by Fourier transform infrared spectrophotometry (FT-IR), differential scanning calorimeter (DSC), powder x-ray diffractometry (PXRD) and the particulate dissolution using type II of USP test.

Results: SV-OA NCDs showed the highest solubility; thus NCDS of SV-OA were characterized by X-ray diffraction showing a new peak at $2 \theta=28.96$ ${ }^{\circ} \mathrm{C}$ and differential scanning calorimeter showed a change of endothermic peak from $134.3^{\circ} \mathrm{C}$ to $69^{\circ} \mathrm{C}$. Infrared spectroscopy indicated that there were no functional group changes from simvastatin, while the dissolution rate increased from $68.22 \%$ to $76.08 \%$.

Conclusion: SV-OA NCDs show an increased profile of solubility and dissolution compared to pure simvastatin.

Keywords: Simvastatin, Non-covalent derivative, Solvent drop grinding, Dissolution

(C) 2020 The Authors. Published by Innovare Academic Sciences Pvt Ltd. This is an open-access article under the CC BY license (http://creativecommons.org/licenses/by/4.0/) DOI: http://dx.doi.org/10.22159/ijap.2020v12i1.35865 Journal homepage: https://innovareacademics.in/journals/index.php/ijap

\section{INTRODUCTION}

Biological availability is a rate value and the quantity of the drug that reaches the blood circulation. Solubility is an important factor in predicting the bioavailability of drugs in blood circulation. Often, drugs that have poor solubility in water also show low bioavailability, so the dissolution rate is the rate-limiting step in the absorption process of drugs in the body. The solubility of a drug is related to its physicochemical properties $[1,2]$.

Simvastatin is a drug that inhibits the action of the $\mathrm{HMG}-\mathrm{CoA}$ reductase enzyme, thereby helping to reduce cholesterol levels in the blood. Based on the results of the Scandinavian Simvastatin Survival Study (4S) and The Heart Protect Study (HPS), simvastatin can reduce the incidence of ischemic stroke, myocardial infarction, and death in cardiovascular patients with atherosclerosis and hypercholesterolemia [3].

Based on the Biopharmaceutical Classification System (BCS), simvastatin is a class II drug group that has low water solubility but high permeability. High solubility can increase the bioavailability of drugs, so solubility is a determining factor in the quantity of the drug reaching the systemic circulation system [4]. Therefore, efforts should be made to increase the solubility of simvastatin to increase its bioavailability.

There are various ways to increase the speed of testing, the rate of dissolution or solubility of a drug, including the pro-drug approach, salt form synthesis, particle size reduction, complex formation, physical shape changes, solid dispersion, spray drying, and hot-melt extrusion. One technique with physical shape changes in the formation of cocrystalline techniques which causes changes in the arrangement of the molecules making up the crystal is caused by the formation of hydrogen bonds between the active substance and the co-former. Changes in the crystal lattice will cause increased changes in solubility [5]. In this study, an effort to increase the rate of dissolution of simvastatin will be investigated using oxalic acid, fumaric acid and nicotinamide as a coformer with a noncovalent derivative approach.

\section{MATERIALS AND METHODS}

\section{Tools}

Spectrophotometer UV-Vis (Specord 200), mechanic agitator (Ohm), Spectrophotometer FTIR (Specord), dissolution tester (Sotax AT7),
X-Ray Diffractometer (Philips PW 1835), Differential Scanning Calorimetry (Pan analytical).

\section{Materials}

The following materials were used: simvastatin (98\%, Teva, Belgium), nicotinamide (Sigma Aldrich), fumaric acid (Sigma Aldrich), oxalic acid (Merck), methanol (Merck), sodium dodecyl sulfate (Merck), sodium phosphate (Merck), and sodium hydroxide (Merck)

\section{Methods}

Production of simvastatin NCDs by the solvent drop grinding method

Simvastatin (SV) was mixed in a 1:1 ratio with nicotinamide (NK), oxalic acid (AO), or fumaric acid (AF) in a mortar and then crushed for $20 \mathrm{~min}$ with the dropwise addition of methanol.

\section{Saturated solubility test}

The equivalent to $20 \mathrm{mg}$ simvastatin was dissolved with $10 \mathrm{ml}$ aquades in an Erlenmeyer, placed in a mechanical agitator for $48 \mathrm{~h}$ at room temperature $\left(25^{\circ} \mathrm{C}\right)$ and then the saturated solubility was measured by UV spectrophotometry in the wavelength range of 247-257 nm [6].

\section{Characterization of NCDs}

$\mathrm{X}$-ray diffraction analysis

The crystal structure was analyzed using a Powder X-Ray Diffractometer (Philips PW 1835), with the following conditions: target/filter (monochromator) Cu, voltage $40 \mathrm{kV}$, current $30 \mathrm{~mA}$, slit width of 0.2 inches, with a scanning speed of $0.2-0.5 \%$ min and scanning distance $2 \theta=5-60^{\circ}[6]$.

\section{Fourier-transform infrared spectroscopy (FTIR)}

Powder-shaped samples were mixed with potassium bromide crystals at a molar ratio of 1:10 and crushed until homogeneous, then compressed with a pressure of 20 Psi using a $\mathrm{KBr}$ plate press. Spectra were measured in the range of $4000-400 \mathrm{~cm}^{-1}$ using a FTIR spectrophotometer [6]. 


\section{Differential scanning calorimetry (DSC)}

A sample of 3-5 mg was placed in the device programmed in a temperature range of $50-350^{\circ} \mathrm{C}$ with a heating speed of $10^{\circ} \mathrm{C} / \mathrm{min}$ [6].

\section{Dissolution test}

The dissolution rate test was conducted based on USP30-NF25 using Apparatus 2 (paddle) with a speed of $50 \mathrm{rpm}$ for $30 \mathrm{~min}$ and $900 \mathrm{ml}$ media buffer solution $\mathrm{pH} 7$ at $37 \pm 0.2^{\circ} \mathrm{C}$. Periodically every $10 \mathrm{~min}, 5$ ml was sampled and the media replaced with the same volume during the test. Samples were then measured using UV spectrophotometry in the wavelength range of $247-257 \mathrm{~nm}$ to calculate the dissolution rate [6].

\section{RESULTS AND DISCUSSION}

Production of simvastatin NCDs by the solvent drop grinding method

Simvastatin co-crystals are made using the solvent drop grinding (SDG) method. This method is used because it requires only a few solvents where the solvent is dropped during grinding so it is more cost-effective and more environmentally friendly than the solutionbased method [7]. Co-crystals are made by mixing simvastatin with co-former using a 1: 1 equimolar ratio (table 1). The comparison used refers to some previous research journals and theses that report the best results of NCDs formed with a 1: 1 equlmolar ratio [8, 9]. Co-former is used to help the formation of simvastatin co-crystals where the ethanol solvent functions as a catalyst. The active and coformer substances must have a number of donors and hydrogen bond acceptors. This hydrogen bond is an important bond in the formation of NCDs because the more hydrogen bonds, the solubility of a substance will increase. Another requirement of the co-former is that it must be pharmacologically acceptable, non-toxic and pharmacologically inert and can be easily dissolved in water. Three co-former used in this study fulfills these requirements. In addition, these three co-formers were reported to be proven to form cocrystals through hydrogen bonds $[5,8,9,11,12]$. In the process of making NCDs, weight loss ranges from 16-20\%. Losses occur because there is material left behind at the time of final weighing after grinding.

Table 1: Comparison of simvastatin and co-former weights

\begin{tabular}{lll}
\hline API: co-former & Molar comparison & Weight comparison (mg) \\
\hline SV: NK & $1: 1$ & $100: 29$ \\
SV: AF & $1: 1$ & $100: 22$ \\
SV: AO & $1: 1$ & $100: 24$ \\
\hline
\end{tabular}

Number of experiment $(n=3)$

\section{Solubility test results}

The solubility test was conducted on simvastatin and the simvastatin NCDs with the three co-formers, namely nicotinamide, fumaric acid and oxalic acid. The solubility test was conducted to determine the effect of the co-former which gave the highest increase in the solubility of the three co-formers used. From the solubility test results, the co-former which formed the highest solubility was oxalic acid (3 ppm; fig. 1).

\section{NCDs characterization}

\section{Powder X-ray diffraction}

The results of X-ray diffraction showed the formation of a new peak on the diffractogram at $2 \theta$ at $28.96^{\circ}$. Changes in diffraction patterns and the formation of new peaks on diffractograms indicate the formation of NCDs [13].

\section{FT-IR spectrophotometric analysis}

Infrared spectroscopy tests were performed on standard simvastatin, oxalic acid, and simvastatin co-crystals. Infrared spectroscopy is often used to detect interactions between drugs and coformer in NCDs. Infrared spectroscopy can detect cocrystal formations, as seen from the presence of hydrogen bonds. Cocrystallization between simvastatin with oxalic acid causes complexation between the two.
The interaction between the two substances is linked by hydrogen bonds. Hydrogen bonds are formed due to the presence of a carbonyl group from simvastatin which will bind to the hydroxy group on oxalic acid. The hydrogen bonding spectrum will appear at wavenumbers $3600-3200 \mathrm{~cm}^{-1}[14]$

Based on the results of the infrared absorption spectrum, the interaction of hydrogen bonds between simvastatin and oxalic acid was evident as the absorption band $\mathrm{C}=\mathrm{O}$ ester of the standard simvastatin at $1700.32 \mathrm{~cm}^{-1}$ shifted to $1704.18 \mathrm{~cm}^{-1}$ on the simvastatin co-crystals. This indicates that the expected hydrogen bonds have form3ed in the NCDs. Electronegative elements tend to attract electrons in between the carbon and oxygen atoms in the $\mathrm{C}=\mathrm{O}$ bond, so that the bond becomes stronger; therefore the vibration band $\mathrm{C}=\mathrm{O}$ bonds appear at higher frequencies [13]. From the shape of the spectrum image, it is evident that there is no change in the functional group of simvastatin.

\section{Differential scanning calorimetry}

The formation of physical interactions between two materials can be estimated using thermal analysis [14] if there is a change in the shape of the crystals, there will be changes in the thermodynamic aspects of a solid [15]. Screening the formation of physical interactions between simvastatin and oxalic acid was detected by DSC, as shown in fig. 4 .

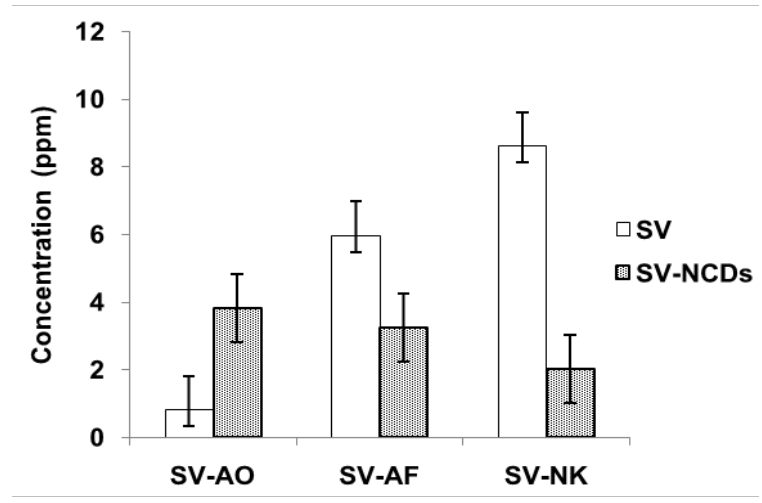

Fig. 1: Solubility of SV and SV-NCDs $(n=3)$ 


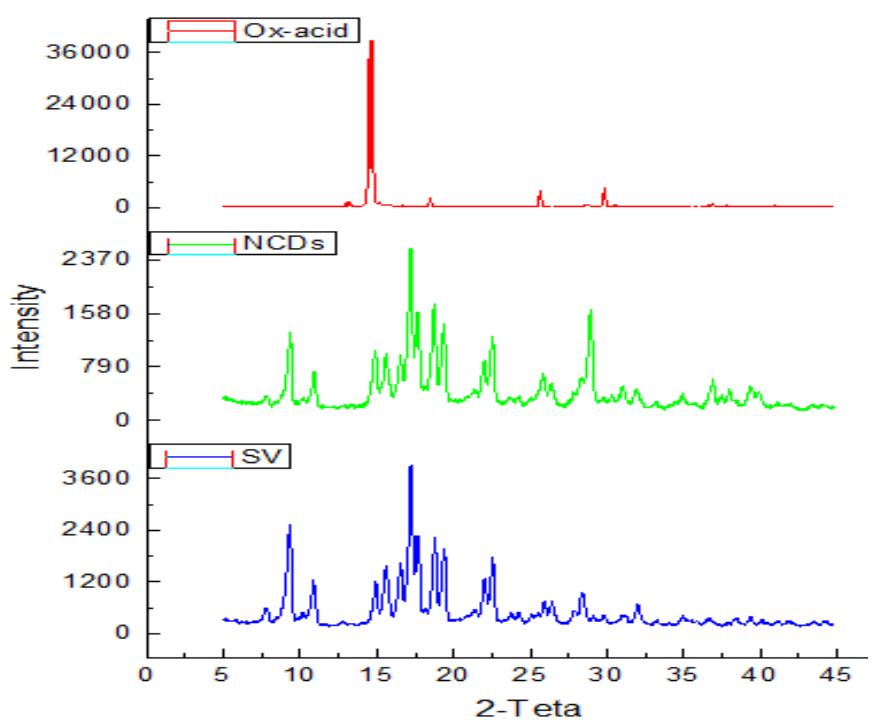

Fig. 2: X-ray diffractogram of SV, NCDs (SV-OXA), and oxalic acid $(n=3)$

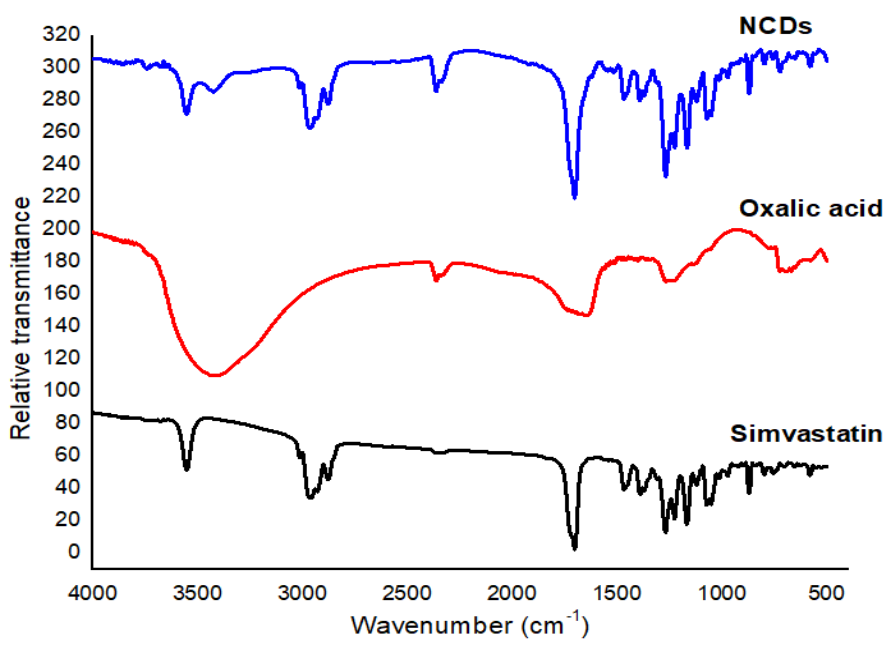

Fig. 3: Infrared spectrum overlay cocrystalline simvastatin (purple) with standard simvastatin (black)

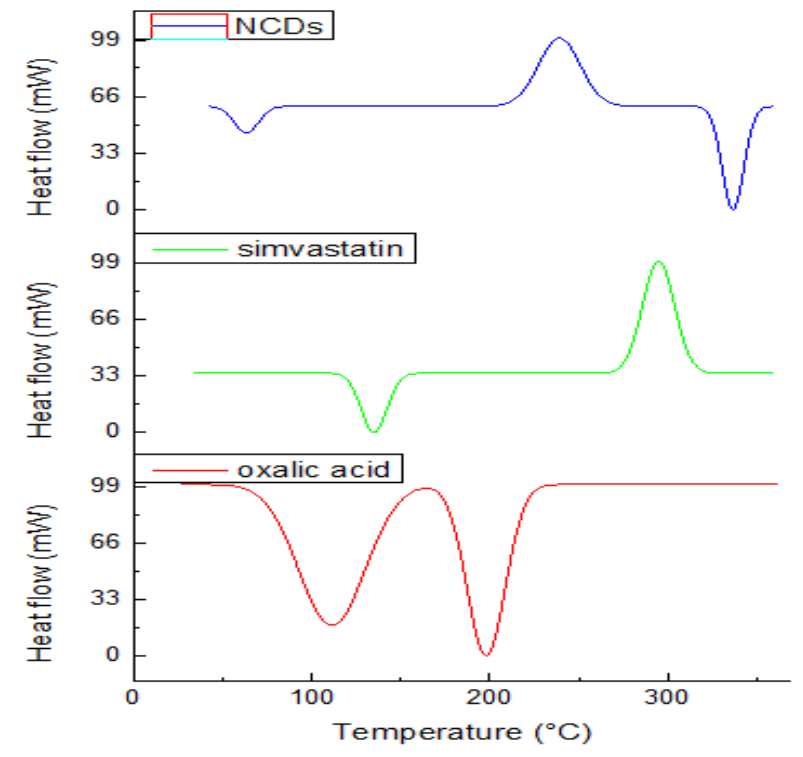

Fig. 4: Thermogram overlay of simvastatin, NCDs, oxalic acid 
The standard simvastatin thermogram shows an endothermic peak, which is the melting process of crystal solids with an onset temperature of $120.8^{\circ} \mathrm{C}$, maximum peak at $134.3^{\circ} \mathrm{C}$ and enthalpy of$105.68 \mathrm{~J} / \mathrm{g}$. The oxalic acid thermogram showed an endothermic peak with an onset temperature of $68.8{ }^{\circ} \mathrm{C}$, maximum peak at 111.2 ${ }^{\circ} \mathrm{C}$ and enthalpy of- $689.77 \mathrm{~J} / \mathrm{g}$. The co-crystal thermogram shows an endothermic peak with an onset temperature of $48.0{ }^{\circ} \mathrm{C}$, maximum peak at $62.9^{\circ} \mathrm{C}$ and enthalpy of-232.35 J/g. Changes in the values of the maximum onset, peak temperatures and enthalpy values show the different characteristics of standard simvastatin, co-former oxalic acid and the resulting NCDs. It appears that there is a decrease in the value of the onset temperature, the maximum peak and the enthalpy value, indicating that NCDs require less heat than the standard simvastatin (1).

\section{Dissolution rate test}

The dissolution rate was measured by the amount of active substance dissolved in a certain time in a known volume of the liquid medium at a relatively constant temperature to determine how much standard simvastatin and NCDs were dissolved in a certain condition. There was an increase in the dissolution rate of standard simvastatin with NCDs of $3.14 \%$ at the $10^{\text {th }}$ minute; $5.53 \%$ at $20 \mathrm{~min}$ and $7.86 \%$ at $30 \mathrm{~min}[16,17]$.

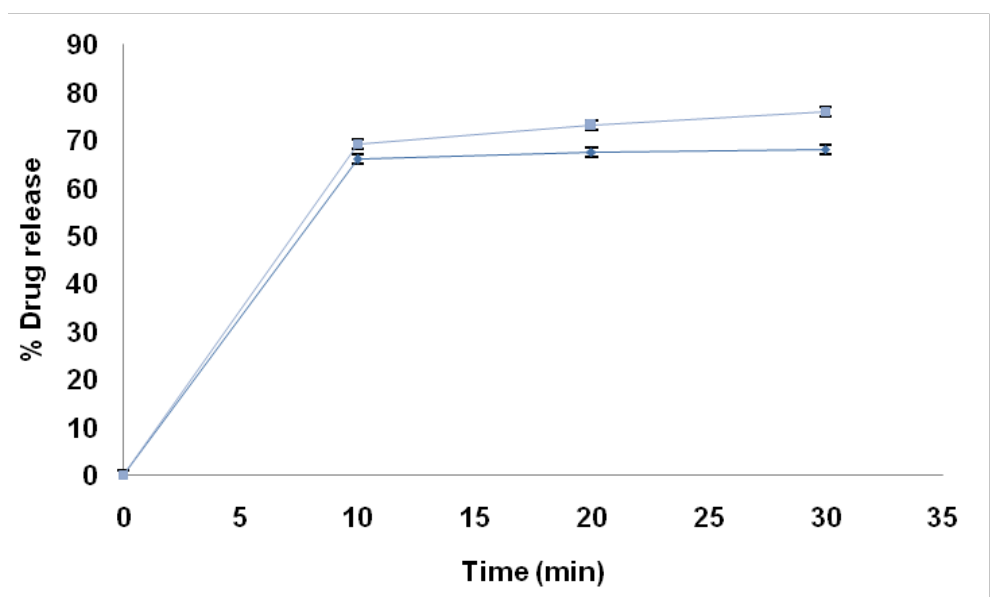

Fig. 5: Dissolution profile of simvastatin ( $\square)$ and NCDs ( $A)(n=3)$

\section{CONCLUSION}

Simvastatin crystals were prepared using the SDG method. Characterization of the crystals by X-ray diffraction revealed a new peak on the diffractogram at $2 \theta=28.96^{\circ}$ and differential scanning calorimetry showed changes in the endothermic peak from $134.3^{\circ} \mathrm{C}$ to $62.9^{\circ} \mathrm{C}$, while IR spectroscopy showed that there was no change in the functional group of simvastatin. The solubility test results showed the highest increase in solubility was achieved by cocrystals formed by oxalic acid ( $3 \mathrm{ppm})$ and the dissolution rate increased from $68.22 \%$ to $76.08 \%$. Further research is needed to test the bioavailability and stability of the resulting co-crystals, as well as investigate other methods and co-formers to produce cocrystals that have the best solubility.

\section{ACKNOWLEDGMENT}

We thank the Higher Education Ministry for Higher Education for the support of this research.

\section{AUTHORS CONTRIBUTIONS}

All the authors have contributed equally.

\section{CONFLICT OF INTERESTS}

No conflict of interest declared in this research

\section{REFERENCES}

1. Racz I. Drug formulation. John Wiley and Sons; 1989.

2. Shargel L, Yu ABC. Applied biopharmaceutics and pharmacokinetics. 4th Edit. Norwalk CT Appleton Lange; 1999. p. 573605.

3. Zheng X, Hu SJ. Effects of simvastatin on cardiohemodynamic responses to ischemia-reperfusion in isolated rat hearts. Heart Vessels 2006;21:116-23.

4. Martin A, Swarbrick J, Cammarata A. Physical pharmacy. Philadelphia: LeaandFebiger; 1990. p. 559-637.

5. Mirza S, Miroshnyk I, Heinamaki J, Yliruusi J. Co-crystals: an emerging approach for enhancing properties of pharmaceutical solids. Dosis 2008;24:90-6.
6. Sopyan I, Fudholi A, Muchtaridi M, Puspitasari I. A simple effort to enhance solubility and dissolution of simvastatin using cocrystalization. Int J Pharm Pharm Sci 2016;8:342-6.

7. Trask AV, Jones W. Crystal engineering of organic cocrystals by the solid-state grinding approach. In: Organic solid-state reactions. Springer; 2005. p. 41-70.

8. Zaini E, Halim A, Soewandhi SN, Setyawan D. [Peningkatan laju pelarutan trimetoprim melalui metode kokristalisasi dengan nikotinamida]. J Farm Indones 2011;5:205-12.

9. Putra OD, Nugrahani I, Ibrahim S, Uekusa H. Pembentukan padatan semi kristalin dan ko-kristal parasetamol. J Mat Sains 2012;17:1-6.

10. Sekhon BS. Pharmaceutical co-crystals-a review. Ars Pharm 2009;5:99-100.

11. Sopyan I, Fudhloli A, Muchtaridi M, Sari IP, Permatasari D. A novel of derivative spectrophotometry as rapid and accurate method in application of simvastatin co-crystal assay. Int J Res Pharm Sci 2017;20:301-6.

12. Bag PP, Patni M, Reddy CM. A kinetically controlled crystallization process for identifying new co-crystal forms: fast evaporation of solvent from solutions to dryness. Cryst Eng Comm 2011;13:5650-2.

13. Harmita H. Buku ajar analisis fisikokimia]. Jakarta: Departemen Farmasi FMIPA UI; 2006.

14. Brittain HG. Theory and principles of polymorphic systems. In: Polymorphism in Pharmaceutical Solids. Informa Healthcare USA: New York; 2009.

15. Nugrahani I. Identifikasi interaksi padatan bahan aktif dan pengaruh interaksi amoksisilina trihidrat-kalium klavulanat terhadap potensi dan profil farmakokinetika]. Institut Teknologi Bandung; 2009.

16. Sopyan I, Sari IM, K IS. Solid state characterization of a novel physical interaction (paracetamil-chlorfeniramine maleate). Int J Appl Pharm 2018;6:21-5.

17. Sopyan I. Co-crystallization: a tool to enhance solubility and dissolution rate of simvastatin. J Young Pharm 2017;9:183-6.

18. Sopyan I, Fudholi A, Muchtaridi M, Sari IP. Simvastatinnicotinamide co-crystal: design, preparation and preliminary characterization. Trop J Pharm Res 2017;16:297. 